\title{
Does 'The Belt and Road Initiative' Promote the Economic Growth of Key Participating Provinces? Evidence from a Quasi-Natural Experiment Design
}

\author{
Shan $\mathrm{Gao}^{1} \&$ Maoguo $\mathrm{Wu}^{1}$ \\ ${ }^{1}$ SILC Business School, Shanghai University, Shanghai, China \\ Correspondence: Maoguo Wu, SILC Business School, Shanghai University, Shanghai, 20 Chengzhong Road, \\ Jiading District, China. Tel: 86-21-699-80028-85101. E-mail: wumaoguo@ shu.edu.cn
}

Received: March 8, 2020

Accepted: April 13, 2020

Online Published: April 20, 2020

doi:10.5539/ijef.v12n5p101

URL: https://doi.org/10.5539/ijef.v12n5p101

\begin{abstract}
As a new Chinese national strategy, 'The Belt and Road (B\&R) Initiative' has attracted substantial interest with its broad development prospect and huge economic impetus. However, existing research is not comprehensive due to the limitation of specific industry and there are few empirical studies. This paper adopted the panel data of key participating provinces in China from 2008 to 2017 according to the China City Statistical Yearbook to fill in the research gap. Around the issue of whether the B\&R initiative promotes the economic development of Chinese key participating provinces along the routes, this paper proposed three hypotheses and used DID, PSM-DID and DDD methods to study relevant factors and the influencing mechanism. The empirical results show that the B\&R policy could promote the overall economic development of participants on the whole, despite a certain degree of policy effect lag. Moreover, after the division of geographical location and administrative level in the eastern and west-central regions of China, the study found that the B\&R initiative has significantly facilitated the advancement of the economy in the west-central areas, especially the less developed regions. In addition, after the classification of marketization degree, it is found that the B\&R policy has a greater promoting effect on regions with high marketization degree than those with low marketization degree. Through the mechanism test, it is discovered that the tertiary industry is the main economic accelerator for growth in central and western China. Finally, based on the empirical results, this paper provided policy suggestions to further implement the B\&R strategy.
\end{abstract}

Keywords: B\&R, key participating provinces, DID, PSM-DID, DDD

\section{Introduction}

In the context of globalization, the sound growth momentum in China is of great significance to the reviviscence and balanced development of the world economy. Put forward at the end of 2013, the global Chinese strategy 'The Belt and Road (B\&R) Initiative' follows in the footsteps of the ancient Silk Road initiatives to continuously realize the interconnection between Asia, Africa, and Europe. This win-win economic strategy is aimed at deepening the regional collaboration of facility networks, trade, and investments, which involves 65 countries with an estimated GDP of 21 trillion USD.

From this point of view, the B\&R strategy is not only cooperation among the participating countries, but also a tremendous development opportunity within China, which connects the majority of Chinese areas based on 18 provinces and 25 cities. These areas have made remarkable progress in terms of flows of capital and talents, technology and infrastructure construction in recent years. In light of these substantial achievements of the areas along the routes, the objective of this study is to determine whether it is the B\&R policy that enhances economic growth and to unravel the affecting factors and mechanism of this initiative.

Although extensive research has been carried out regarding the evaluation of B\&R effects on a country level from the qualitative perspective, most of which failed to specify the influences on key participating provinces within China comprehensively and the research is limited to specific industries. To develop an in-depth understanding of the B\&R strategy and provides an empirical basis for further policy implementation, the panel data in Chinese key participating provinces from 2008 to 2017 was adopted mainly according to China City Statistical Yearbook. Furthermore, quantitative models integrating DID, PSM-DID and DDD were employed in 
the data processing and analysis.

The remaining part of the paper proceeds as follows. Section 2 presents an overview of the characteristics and influencing mechanism of major development strategies in China with the derived hypotheses for this dissertation. Section 3 provides the data used and descriptive statistical results. Section 4 analyzes the empirical results of the B\&R strategy and Section 5 concludes the paper and offers corresponding recommendations.

\section{Related Literature}

Gan et al. (2011) analyze the impacts of the Great Western Development Strategy in China, which was enforced since 2000. It is highlighted that although the policy promotes the overall improvements according to the social and economic indicators, the unbalanced development between the eastern and western regions reveals a deterioration trend. Later, more research has focused on the policy trap. Sun et al. (2019) regard the Great Western Development Strategy as a quasi-natural experiment and adopt the PSM-DID method to evaluate the influences on regional technological innovation. The results and mechanism verify the pitfall as a consequence of the crowding-out effects. The over-concentrated investment in infrastructure leads to the neglect of driving forces of technological progress such as urbanization level, human capital, and FDI. Deng et al. (2020) extend the research with the static and dynamic model and data for two decades recently from 1978 to 2018. It states that the policy effects are heterogeneous in the time and space dimensions, which generally show an inverted U-shaped trend. Moreover, the regional differences of the policy effects are large at the beginning, whereas they tend to be stable over time.

He (2017) uses 13 provinces in the northeast and east China as research samples to analyze the Chinese Revitalization of the Northeast Strategy. The policies regarding investment, talent introduction, social life security, and technological progress are proved effective for economic recovery, while in the industrial and opening up aspects, the relevant implementations are inefficient to some extent. Jia (2018) focuses on both the short-term and long-term perspectives and further confirms the positive factors in the influencing mechanism,. It is emphasized that capital, labor force and technology are three major elements to drive economic growth. At present, the strategy is in a new stage since 2016. However, the effects are unobvious as the economic condition in northeast China is still declining (Hu \& Chen, 2019).

Based on the research above, a much-debated question can be found that whether such national strategies will promote economic development is inconclusive. The lag of policy effects and the heterogeneity of implementation areas are factors of great significance for policy evaluation. Hence, this dissertation built three hypotheses:

$\boldsymbol{H}_{\boldsymbol{I}}$ : The B\&R policy enhances the overall economic growth of key participating provinces along the routes.

$\boldsymbol{H}_{2}$ : There is a lag in $B \& R$ policy effects.

$\boldsymbol{H}_{3}$ : There are regional differences in B\&R policy effects.

\section{The Data}

This paper used the panel data of key participating provinces in China from 2008 to 2017, to evaluate the economic impacts of the B\&R policy on these areas along the Belt and Road for ten years. The historical data mainly originates from the China City Statistical Yearbook. There are two major reasons regarding the choice of the time interval from 2008 to 2017: (1) In 2013, the B\&R initiative was first proposed by President Xi Jinping. In order to make a before-and-after comparison, this year should be regarded as a sample segmentation time point. (2) In 2008, the world financial crisis occurred and the economic data fluctuated greatly, which should be considered as another time division point. Meanwhile, the data sample for studying a policy needs to be relatively large. As to ensure universality, this paper selected the year 2008 as the sample starting point and year 2017 as the sample ending point. 
Table 1. Detailed calculation methods and definitions of all variables

\begin{tabular}{|c|c|c|}
\hline Variable Type & Variable Name & Definition \\
\hline \multirow{2}{*}{ Explained Variable } & $\operatorname{lngdp}$ & The logarithm of regional GDP \\
\hline & lngdpper & The logarithm of regional GDP per capita \\
\hline \multirow{3}{*}{ Explanatory Variable } & after & Take the value of 1 if it is the year after the $B \& R$ is implemented and 0 otherwise \\
\hline & treated & Take the value of 1 if it is an area along the $B \& R$ and 0 otherwise \\
\hline & cenwest & Take the value of 1 if it is the central and western regions and 0 otherwise \\
\hline \multirow{9}{*}{ Control Variable } & industry & The output value of the secondary industry accounts for the proportion of regional GDP \\
\hline & tertiary & The output value of the tertiary industry accounts for the proportion of regional GDP \\
\hline & far & The logarithm of the region's fixed assets investment for the year is taken \\
\hline & employ & The proportion of employees in the total population of the region \\
\hline & wage & Take the logarithm of wages in the area \\
\hline & saving & The proportion of household savings in GDP at the end of the year \\
\hline & consume & The logarithm of total retail sales of consumer goods \\
\hline & gov & The proportion of government budget expenditure in regional GDP \\
\hline & tech & Government spending on science and technology as a share of GDP \\
\hline
\end{tabular}

According to the previous research, GDP and the per capita GDP of each city are regarded as the explained variables by setting 2008 as the benchmark year. In the sample interval, if the city belongs to those along the B\&R after the policy was implemented in 2013, the value is 1 ; instead, it is assigned to 0 .

In order to consider other factors, this paper selected 9 control variables. Firstly, since the secondary industry has replaced the dominant position of the primary industry and the status of the tertiary industry is becoming prominent, these two indicators were used to measure the degree of industrialization and urban and national development. Furthermore, the level of fixed asset investment was selected as regional economic development is closely related to infrastructure construction. For the people's wellbeing, the thesis used employment and wage rate to measure the impacts of the policy on ensuring the living standards. In terms of expenditure and consumption, saving rates of Chinese residents, social consumption level, government spending and science, and technology input were all included as important factors. With 2860 observations in each group, the descriptive statistical results of various variables are shown in Table 2.

Table 2. Descriptive statistics of control variables

\begin{tabular}{ccccc}
\hline Control Variable & Mean & Standard Deviation & Min. & Max. \\
\hline industry & 49.415 & 10.662 & 14.95 & 90.97 \\
tertiary & 37.294 & 9.208 & 8.58 & 80.23 \\
far & 73.198 & 76.878 & 8.723 & 3915.453 \\
employ & 12.455 & 17.336 & 2.345 & 613.158 \\
wage & 237.571 & 92.971 & 37.748 & 1959.475 \\
saving & 72.77 & 91.7 & 6.736 & 4719.198 \\
consume & 14.664 & 1.072 & 4.914 & 17.958 \\
gov & 18.389 & 17.776 & .496 & 638.838 \\
tech & .22 & .701 & 0 & 34.674 \\
\hline
\end{tabular}

\section{Analysis of Empirical Results}

\subsection{Overall Policy Effects on Economy}

In policy assessment or causal analysis, the DID method needs to meet the common trend hypothesis to avoid the self-selection problem of city samples selected. In this paper, an interaction term was created between two dummy variables, namely, year and experimental group, to capture the difference in economic growth between the key participating provinces each year. As is shown from the following Table 3, the DID item is significant, while the treated items are insignificant before 2013 and then become significant after 2013. These results indicate that the common trend hypothesis is valid and the DID regression can be performed. 
Table 3. Results of common trend hypothesis test

\begin{tabular}{|c|c|c|}
\hline & (1) lngdp & (2) lngdpper \\
\hline did & $\begin{array}{c}-0.103^{* * *} \\
(-4.85)\end{array}$ & $\begin{array}{c}-0.0970^{* * *} \\
(-3.83)\end{array}$ \\
\hline B\&R*year2008 & & \\
\hline B\&R*year2009 & $\begin{array}{c}0.116^{* * *} \\
(7.74)\end{array}$ & $\begin{array}{c}0.109^{* * *} \\
(6.13)\end{array}$ \\
\hline B\&R*year2010 & $\begin{array}{c}0.223^{* * * *} \\
(14.93)\end{array}$ & $\begin{array}{c}0.185^{* * * *} \\
(10.40)\end{array}$ \\
\hline B\&R*year2011 & $\begin{array}{c}0.339^{* * *} \\
(22.66)\end{array}$ & $\begin{array}{l}0.329^{* * * * *} \\
(18.51)\end{array}$ \\
\hline B\&R*year2012 & $\begin{array}{c}0.454^{* * *} \\
(30.31)\end{array}$ & $\begin{array}{l}0.427^{* * * *} \\
(24.05)\end{array}$ \\
\hline B\&R*year2013 & $\begin{array}{l}0.545^{* * *} \\
(36.42)\end{array}$ & $\begin{array}{l}0.513^{* * * *} \\
(28.88)\end{array}$ \\
\hline B\&R*year2014 & $\begin{array}{l}0.615^{* * *} \\
(41.07)\end{array}$ & $\begin{array}{l}0.528^{* * * *} \\
(29.72)\end{array}$ \\
\hline B\&R*year2015 & $\begin{array}{c}0.687^{* * * *} \\
(45.87)\end{array}$ & $\begin{array}{l}0.649^{* * * *} \\
(36.49)\end{array}$ \\
\hline B\&R*year2016 & $\begin{array}{c}0.743^{* * *} \\
(49.60)\end{array}$ & $\begin{array}{l}0.695^{* * * *} \\
(39.12)\end{array}$ \\
\hline B\&R*year2017 & $\begin{array}{c}0.808^{* * * *} \\
(53.95)\end{array}$ & $\begin{array}{c}0.760^{* * * *} \\
(42.74)\end{array}$ \\
\hline Controls & Yes & Yes \\
\hline$N$ & 2860 & 2860 \\
\hline$R^{2}$ & 0.813 & 0.734 \\
\hline
\end{tabular}

Note. The parentheses are the t-test values, ${ }^{*}, * *, * * *$ indicate significance level of $10 \%, 5 \%$, and $1 \%$, respectively.

As another opening-up strategy of China in the 21 st century, the B\&R initiative can be seen as a quasi-natural experiment. Utilizing the DID method, we can evaluate the net effects of the policy on economic development and growth of key participating provinces along the routes. The regression results are shown in Table 4.

Table 4. The results of DID method

\begin{tabular}{|c|c|c|c|c|}
\hline & $\begin{array}{c}(1) \\
\text { lngdp }\end{array}$ & $\begin{array}{c}(2) \\
\text { lngdpper }\end{array}$ & $\begin{array}{c}(3) \\
\operatorname{lngdp}\end{array}$ & $\begin{array}{c}\text { (4) } \\
\text { lngdpper }\end{array}$ \\
\hline \multicolumn{5}{|l|}{ treated } \\
\hline \multirow[t]{2}{*}{ after } & $0.433^{* * *}$ & $0.397^{* * * *}$ & $0.185^{* * *}$ & $0.154^{* * * *}$ \\
\hline & (39.67) & $(34.63)$ & $(19.44)$ & $(12.77)$ \\
\hline \multirow[t]{2}{*}{ did } & $-0.0501^{\text {**** }}$ & -0.0238 & $0.0177^{*}$ & $0.0459^{\text {**** }}$ \\
\hline & $(-3.22)$ & $(-1.46)$ & (1.80) & (3.67) \\
\hline \multirow[t]{2}{*}{ industry } & & & $0.0406^{* * *}$ & $0.0469^{* * *}$ \\
\hline & & & $(28.31)$ & $(25.74)$ \\
\hline \multirow[t]{2}{*}{ tertiary } & & & $0.0331^{* * * *}$ & $0.0379^{* * * *}$ \\
\hline & & & (18.75) & $(16.87)$ \\
\hline \multirow[t]{2}{*}{ far } & & & $0.000598^{* * * *}$ & $0.000735^{\text {**** }}$ \\
\hline & & & $(4.53)$ & (4.37) \\
\hline \multirow[t]{2}{*}{ employ } & & & $-0.000409^{* *}$ & -0.000272 \\
\hline & & & $(-2.17)$ & $(-1.13)$ \\
\hline \multirow[t]{2}{*}{ wage } & & & $0.000155^{* * * *}$ & $0.000158^{\text {**** }}$ \\
\hline & & & $(4.45)$ & (3.57) \\
\hline \multirow[t]{2}{*}{ saving } & & & $-0.00150^{* * * *}$ & $-0.000623^{* * *}$ \\
\hline & & & $(-14.17)$ & $(-4.64)$ \\
\hline \multirow[t]{2}{*}{ consume } & & & $0.308^{* * * *}$ & $0.269^{* * *}$ \\
\hline & & & $(32.38)$ & $(22.22)$ \\
\hline \multirow[t]{2}{*}{ gov } & & & $0.00179^{* * * *}$ & $0.00101^{* *}$ \\
\hline & & & (4.98) & $(2.21)$ \\
\hline \multirow[t]{2}{*}{ tech } & & & -0.0146 & -0.0168 \\
\hline & & & $(-1.39)$ & $(-1.26)$ \\
\hline \multirow[t]{2}{*}{ _cons } & $15.59^{* * *}$ & $9.746^{* * *}$ & $7.925^{\text {*** }}$ & $2.104^{* * * *}$ \\
\hline & $(3169.22)$ & (1886.26) & $(50.08)$ & $(10.45)$ \\
\hline$N$ & 2860 & 2860 & 2860 & 2860 \\
\hline$R^{2}$ & 0.519 & 0.464 & 0.815 & 0.699 \\
\hline
\end{tabular}

Note. The parentheses are the t-test values, *,**,*** indicate significance level of $10 \%, 5 \%$, and $1 \%$, respectively. 
It can be found that when DID regression is carried out without adding other control variables, the B\&R strategy has no significant promoting effects on the GDP of key participating provinces along the routes, or there is even a negative effect of slowing down the growth rate of regional GDP. However, after considering the control variables, the results demonstrate that the B\&R initiative drives the increase of GDP (under 10\% significance level) and GDP per capita (under 1\% significance level) of the provinces along the routes, which verifies the $\boldsymbol{H}_{\boldsymbol{I}}$. In detail, industrialization level, industrial structure, fixed asset investment level, wage rate, social consumption, and government scale all play an essential role in promoting the economic growth of the B\&R areas (under 1\% significance level). On the contrary, the employment level has a significant inhibitory effect on regional GDP results (under 5\% significance level), though it is insignificant in terms of per capita GDP. The high saving rate also has a significant restraining effect on the economic growth of the areas along the Belt and Road. Besides, the factor of government expenditures on scientific and technological areas is insignificant in the recent five-year development. This consequence may result from insufficient investments or low efficiency of some policies enforced by the local government.

In order to overcome the systematic errors in the changing trend of economic growth in B\&R regions and non- $\mathrm{B} \& \mathrm{R}$ regions, and reduce the wrong estimations of DID method, the PSM-DID method was adopted. When utilizing this method, the GDP (lngdp) and GDP per capita (lngdpper) were used to perform Logit regression on the control variables to obtain the propensity matching score with Kernel matching. The Logit regression outcome shows that each covariable has strong explanatory power for treatment variables and it passed the hypothesis test of the balance of covariates. In other words, the feasibility of the PSM-DID method is verified.

Table 5. The results of PSM-DID method

\begin{tabular}{|c|c|c|}
\hline & $\begin{array}{c}(1) \\
\text { lngdp }\end{array}$ & $\begin{array}{c}(2) \\
\text { lngdpper }\end{array}$ \\
\hline \multicolumn{3}{|l|}{ treated } \\
\hline \multirow[t]{2}{*}{ after } & $0.0973^{* * *}$ & $0.0764^{* * *}$ \\
\hline & (11.87) & $(6.70)$ \\
\hline \multirow[t]{2}{*}{ did } & 0.00536 & $0.0320^{* * *}$ \\
\hline & $(0.66)$ & $(2.82)$ \\
\hline \multirow[t]{2}{*}{ industry } & $0.0299^{* * *}$ & $0.0374^{* * *}$ \\
\hline & $(24.61)$ & (22.16) \\
\hline \multirow[t]{2}{*}{ tertiary } & $0.0187^{* * *}$ & $0.0253^{* * *}$ \\
\hline & (12.36) & (11.99) \\
\hline \multirow[t]{2}{*}{ far } & $0.000326^{* * *}$ & $0.000485^{* * *}$ \\
\hline & (2.98) & (3.18) \\
\hline \multirow[t]{2}{*}{ employ } & $0.00229^{* * *}$ & 0.000637 \\
\hline & $(3.81)$ & $(0.76)$ \\
\hline \multirow[t]{2}{*}{ wage } & $0.0000605^{* *}$ & $0.0000959^{* *}$ \\
\hline & $(2.06)$ & $(2.35)$ \\
\hline \multirow[t]{2}{*}{ saving } & $-0.00121^{* * *}$ & $-0.000398^{* * * *}$ \\
\hline & $(-13.80)$ & $(-3.26)$ \\
\hline \multirow[t]{2}{*}{ consume } & $0.540^{* * *}$ & $0.477^{* * *}$ \\
\hline & (52.45) & (33.36) \\
\hline \multirow[t]{2}{*}{ gov } & $0.000852^{* * *}$ & 0.000157 \\
\hline & $(2.74)$ & $(0.36)$ \\
\hline \multirow[t]{2}{*}{ tech } & -0.00831 & -0.00581 \\
\hline & $(-0.93)$ & $(-0.47)$ \\
\hline \multirow[t]{2}{*}{ _cons } & $5.626^{* * *}$ & 0.0316 \\
\hline & (38.76) & $(0.16)$ \\
\hline$N$ & 2827 & 2827 \\
\hline$R^{2}$ & 0.876 & 0.755 \\
\hline
\end{tabular}

Note. The parentheses are the t-test values, *,**,*** indicate significance level of $10 \%, 5 \%$, and $1 \%$, respectively.

As is shown in Table 5, the $\boldsymbol{H}_{\boldsymbol{I}}$ is further verified based on the results. For the explained variable lngdp, industry, tertiary, far, employ, wage, consume, and gov all have promoting effects (at least under 5\% significance level). For the explained variable lngdpper, industry, tertiary, far, wage and consume also have significant effects at 
least in the case of the 5\% level. Among these control variables, the low coefficient of wage and high coefficient of industry could manifest that the regional industries are still labor-intensive and relatively backward with manpower as the main productive force. Additionally, two control variables are only significant for lngdpper, namely, employ and gov. It is possible because the employment rate may be stable for society as a whole while it could be random for individuals. Moreover, the function of the government may merely play an indispensable role in the regional layer, whereas there could be limitations that the policies cannot benefit everyone since GDP per capita is calculated in terms of the individuals.

\subsection{Dynamic Effects of the Policy}

With the gradual implementation of the B\&R initiative since 2013, relevant supporting regulations and the understanding and practical capability of the local governments have been improved accordingly. Hence, the ability of the $\mathrm{B} \& \mathrm{R}$ initiative to promote economic growth in the regions along the routes can be positively correlated with time. Table 6 shows the test concerning whether there are dynamic effects.

Table 6. The test of dynamic effects of the B\&R policy

\begin{tabular}{|c|c|c|c|c|}
\hline & $\begin{array}{c}(1) \\
\text { lngdp }\end{array}$ & $\begin{array}{c}(2) \\
\text { lngdpper }\end{array}$ & $\begin{array}{c}\text { (3) } \\
\text { lngdp }\end{array}$ & $\begin{array}{c}(4) \\
\text { lngdpper }\end{array}$ \\
\hline $\begin{array}{c}\text { treated } \\
\text { after }\end{array}$ & $\begin{array}{c}0.433^{* * *} \\
(47.18)\end{array}$ & $\begin{array}{c}0.397^{* * *} \\
(39.42)\end{array}$ & $\begin{array}{l}0.254^{* * *} \\
(29.26)\end{array}$ & $\begin{array}{l}0.213^{* * *} \\
(17.78)\end{array}$ \\
\hline B\&R*year 2008 & $\begin{array}{c}-0.457^{* * *} \\
(-22.42)\end{array}$ & $\begin{array}{l}-0.420^{* * *} \\
(-18.77)\end{array}$ & $\begin{array}{l}-0.289^{* * *} \\
(-21.00)\end{array}$ & $\begin{array}{c}-0.251^{* * *} \\
(-13.18)\end{array}$ \\
\hline B\&R*year2009 & $\begin{array}{c}-0.347^{* * *} \\
(-17.00)\end{array}$ & $\begin{array}{l}-0.325^{* * *} \\
(-14.50)\end{array}$ & $\begin{array}{l}-0.226^{* * *} \\
(-16.82)\end{array}$ & $\begin{array}{c}-0.205^{* * *} \\
(-11.00)\end{array}$ \\
\hline B\&R*year 2010 & $\begin{array}{c}-0.232^{* * *} \\
(-11.37)\end{array}$ & $\begin{array}{c}-0.217^{* * *} \\
(-9.69)\end{array}$ & $\begin{array}{c}-0.152^{* * *} \\
(-11.53)\end{array}$ & $\begin{array}{c}-0.139^{* * *} \\
(-7.67)\end{array}$ \\
\hline B\&R*year2011 & $\begin{array}{c}-0.109^{* * *} \\
(-5.35)\end{array}$ & $\begin{array}{c}-0.0953^{* * *} \\
(-4.25)\end{array}$ & $\begin{array}{c}-0.0537^{* * *} \\
(-4.08)\end{array}$ & $\begin{array}{c}-0.0588^{* * *} \\
(-3.24)\end{array}$ \\
\hline B\&R*year2012 & $\begin{array}{c}0.0934^{* * * *} \\
(4.58)\end{array}$ & $\begin{array}{c}0.0904^{* * *} \\
(4.03)\end{array}$ & $\begin{array}{c}0.0608^{* * *} \\
(4.65)\end{array}$ & $\begin{array}{c}0.0598^{* * *} \\
(3.31)\end{array}$ \\
\hline B\&R*year 2013 & $\begin{array}{c}-0.269^{* * *} \\
(-12.04)\end{array}$ & $\begin{array}{c}-0.213^{* * *} \\
(-8.66)\end{array}$ & $\begin{array}{c}-0.142^{* * * *} \\
(-9.58)\end{array}$ & $\begin{array}{c}-0.0808^{* * *} \\
(-3.93)\end{array}$ \\
\hline B\&R*year2014 & $\begin{array}{c}-0.225^{* * *} \\
(-10.06)\end{array}$ & $\begin{array}{c}-0.200^{* * *} \\
(-8.13)\end{array}$ & $\begin{array}{c}-0.117^{* * *} \\
(-8.07)\end{array}$ & $\begin{array}{c}-0.0847^{* * *} \\
(-4.23)\end{array}$ \\
\hline B\&R*year2015 & $\begin{array}{c}-0.226^{* * *} \\
(-10.11)\end{array}$ & $\begin{array}{c}-0.170^{* * *} \\
(-6.92)\end{array}$ & $\begin{array}{c}-0.0852^{* * *} \\
(-5.89)\end{array}$ & $\begin{array}{c}-0.0472^{* *} \\
(-2.36)\end{array}$ \\
\hline B\&R*year2016 & $\begin{array}{c}-0.181^{* * *} \\
(-8.09)\end{array}$ & $\begin{array}{c}-0.158^{* * *} \\
(-6.42)\end{array}$ & $\begin{array}{c}-0.0531^{* * *} \\
(-3.63)\end{array}$ & $\begin{array}{l}-0.0235 \\
(-1.16)\end{array}$ \\
\hline industry & & & $\begin{array}{c}0.0367^{* * *} \\
(29.45)\end{array}$ & $\begin{array}{c}0.0437^{* * * *} \\
(25.38)\end{array}$ \\
\hline tertiary & & & $\begin{array}{c}0.0282^{* * *} \\
(17.99)\end{array}$ & $\begin{array}{c}0.0341^{* * *} \\
(15.75)\end{array}$ \\
\hline far & & & $\begin{array}{c}0.000458^{* * * *} \\
(4.01)\end{array}$ & $\begin{array}{c}0.000605^{* * *} \\
(3.83)\end{array}$ \\
\hline employ & & & $\begin{array}{c}-0.000217 \\
(-1.33)\end{array}$ & $\begin{array}{c}-0.000109 \\
(-0.48)\end{array}$ \\
\hline wage & & & $\begin{array}{c}0.000182^{* * *} \\
(5.92)\end{array}$ & $\begin{array}{c}0.000183^{* * *} \\
(4.32)\end{array}$ \\
\hline saving & & & $\begin{array}{c}-0.00131^{* * *} \\
(-14.20)\end{array}$ & $\begin{array}{c}-0.000443^{* * *} \\
(-3.47)\end{array}$ \\
\hline consume & & & $\begin{array}{l}0.211^{* * *} \\
(23.93)\end{array}$ & $\begin{array}{c}0.184^{* * *} \\
(15.09)\end{array}$ \\
\hline gov & & & $\begin{array}{c}0.000362 \\
(1.15)\end{array}$ & $\begin{array}{c}-0.000231 \\
(-0.53)\end{array}$ \\
\hline tech & & & $\begin{array}{c}0.000254 \\
(0.03)\end{array}$ & $\begin{array}{c}-0.00542 \\
(-0.43)\end{array}$ \\
\hline _cons & $\begin{array}{c}15.67^{* * *} \\
(2035.99)\end{array}$ & $\begin{array}{c}9.826^{* * *} \\
(1162.78)\end{array}$ & $\begin{array}{l}9.753^{* * *} \\
(64.56)\end{array}$ & $\begin{array}{l}3.676^{* * *} \\
(17.61)\end{array}$ \\
\hline$N$ & 2860 & 2860 & 2860 & 2860 \\
\hline$R^{2}$ & 0.661 & 0.588 & 0.863 & 0.737 \\
\hline
\end{tabular}

Note. The parentheses are the t-test values, *,**,*** indicate significance level of $10 \%, 5 \%$, and $1 \%$, respectively. 
The results indicate that considering the lag of the B\&R policy effects, the impacts on the GDP and regional GDP per capita of key participating provinces along the routes are still insignificant, or even negative to some extent. On the contrary, after nine control variables are adopted, the regression results demonstrate that the B\&R policy has boosted the economic growth effectively. Nevertheless, the details show that the promotion effect of the policy is not as great as expected. Therefore, these findings validate the $\boldsymbol{H}_{2}$. Given this problem, the government is supposed to increase the expansion of the $B \& R$ initiative to better stimulate local economic development.

\subsection{Regional Differences of Policy Effects}

This paper evaluates whether the B\&R policy effects differ in regions. Geographical location (including the eastern and mid-west areas) with the administrative level, and marketization degree are selected as two significant dimensions for analysis.

\subsubsection{Geographical Location and Administrative Level}

Under the case where the common trend hypothesis is rejected, it is specifically assumed that great changes have taken place on the east coast of China before and after the implementation of the B\&R policy. As a result, even if the policy is not implemented, the spillover effects from the east coast of China will lead to different economic development conditions of some related provinces and cities. In other words, the common trend hypothesis is violated and it is necessary to control these differences caused by spillover effects based on the extended DID model. According to the implementation areas of the B\&R policy, this paper separated the eastern regions from the central and western regions in China, setting the former as 0 and the latter as 1.

Table 7. The results of DDD method

\begin{tabular}{|c|c|c|}
\hline & $\begin{array}{c}(1) \\
\text { lngdp }\end{array}$ & $\begin{array}{c}(2) \\
\text { lngdpper }\end{array}$ \\
\hline \multicolumn{3}{|l|}{ treated } \\
\hline after & $\begin{array}{l}0.188^{* * *} \\
(13.06)\end{array}$ & $\begin{array}{c}0.176^{* * *} \\
(9.62)\end{array}$ \\
\hline did & $\begin{array}{l}-0.0106 \\
(-0.64)\end{array}$ & $\begin{array}{c}-0.00573 \\
(-0.27)\end{array}$ \\
\hline \multicolumn{3}{|l|}{$\begin{array}{c}\text { cenwest } \\
\text { trcw }\end{array}$} \\
\hline after*cen & $\begin{array}{c}-0.00648 \\
(-0.43)\end{array}$ & $\begin{array}{c}-0.0326^{*} \\
(-1.69)\end{array}$ \\
\hline ddd & $\begin{array}{c}0.0469^{* *} \\
(2.29)\end{array}$ & $\begin{array}{c}0.0819^{* * * *} \\
(3.14)\end{array}$ \\
\hline industry & $\begin{array}{c}0.0407^{* * *} \\
(28.32)\end{array}$ & $\begin{array}{c}0.0472^{* * * *} \\
(25.87)\end{array}$ \\
\hline tertiary & $\begin{array}{c}0.0332^{* * * *} \\
(18.85)\end{array}$ & $\begin{array}{c}0.0381^{* * * *} \\
(16.99)\end{array}$ \\
\hline far & $\begin{array}{c}0.000582^{* * * *} \\
(4.40)\end{array}$ & $\begin{array}{c}0.000720^{* * * *} \\
(4.29)\end{array}$ \\
\hline employ & $\begin{array}{c}-0.000360^{*} \\
(-1.90)\end{array}$ & $\begin{array}{c}-0.000222 \\
(-0.92)\end{array}$ \\
\hline wage & $\begin{array}{c}0.000166^{* * *} \\
(4.73)\end{array}$ & $\begin{array}{c}0.000168^{* * *} \\
(3.77)\end{array}$ \\
\hline saving & $\begin{array}{c}-0.00150^{* * * *} \\
(-14.18)\end{array}$ & $\begin{array}{c}-0.000621^{* * *} \\
(-4.63)\end{array}$ \\
\hline consume & $\begin{array}{c}0.307^{* * * *} \\
(32.34)\end{array}$ & $\begin{array}{c}0.268^{* * * *} \\
(22.21)\end{array}$ \\
\hline gov & $\begin{array}{c}0.00178^{* * *} \\
(4.96)\end{array}$ & $\begin{array}{c}0.000985^{* *} \\
(2.16)\end{array}$ \\
\hline tech & $\begin{array}{c}-0.0122 \\
(-1.15)\end{array}$ & $\begin{array}{c}-0.0144 \\
(-1.07)\end{array}$ \\
\hline _cons & $\begin{array}{l}7.921^{* * * *} \\
(50.04)\end{array}$ & $\begin{array}{l}2.084^{* * * *} \\
(10.36)\end{array}$ \\
\hline$N$ & 2860 & 2860 \\
\hline$R^{2}$ & 0.816 & 0.700 \\
\hline
\end{tabular}

Note. The parentheses are the t-test values, *,**,*** indicate significance level of $10 \%, 5 \%$, and $1 \%$, respectively. 
As can be seen from Table 7, the variables industry, tertiary, far, wage, consume and gov have significant promoting effects on regional economic growth and per capita GDP along the B\&R in central and western China. Compared with previous analysis in Table 5, Table 7 shows that employment has negative effects instead of promoting effects on regional GDP per capita in central and western China (under 10\% significance level), which indicates that the $\boldsymbol{H}_{3}$ is preliminarily verified. Moreover, it is further confirmed that the higher saving rate tends to hinder economic development for both the eastern regions and the mid-west along the routes.

Among the areas along the $\mathrm{B} \& \mathrm{R}$, there are many megalopolises with strong economic development capacity, such as sub-provincial cities and municipalities directly under the central government. Their historical economic data can have a great impact on the outcome of the regression. In order to avoid the impact of such prior regions on the accuracy of the research, this paper specifically excluded the data of the large cities in the samples for the heterogeneity test with the DID method. Column (1) and (2) show results in the eastern China while column (3) and (4) demonstrate the impacts in the central and western China, which further validate the $\boldsymbol{H}_{\mathbf{3}}$.

Table 8. Administrative level heterogeneity test

\begin{tabular}{|c|c|c|c|c|}
\hline & (1) lngdp & (2) lngdpper & (3) lngdp & (4) lngdpper \\
\hline \multicolumn{5}{|l|}{ treated } \\
\hline \multirow[t]{2}{*}{ after } & $0.188^{* * *}$ & $0.147^{* * *}$ & $0.189^{* * *}$ & $0.164^{* * * *}$ \\
\hline & (19.17) & (11.76) & (12.27) & $(8.35)$ \\
\hline \multirow[t]{2}{*}{ did } & $0.0213^{* *}$ & $0.0487^{* * * *}$ & -0.00740 & -0.00574 \\
\hline & (2.07) & $(3.72)$ & $(-0.42)$ & $(-0.25)$ \\
\hline \multicolumn{5}{|l|}{ cenwest } \\
\hline trew & & & & \\
\hline \multirow[t]{2}{*}{ after*en } & & & -0.00190 & -0.0241 \\
\hline & & & $(-0.12)$ & $(-1.18)$ \\
\hline \multirow[t]{2}{*}{ ddd } & & & $0.0464^{* *}$ & $0.0847^{* * *}$ \\
\hline & & & $(2.14)$ & (3.06) \\
\hline \multirow[t]{2}{*}{ industry } & $0.0403^{* * *}$ & $0.0471^{* * *}$ & $0.0404^{* * *}$ & $0.0474^{* * *}$ \\
\hline & (27.79) & $(25.49)$ & $(27.81)$ & $(25.62)$ \\
\hline \multirow[t]{2}{*}{ tertiary } & $0.0324^{* * * *}$ & $0.0382^{* * *}$ & $0.0325^{* * *}$ & $0.0384^{* * * *}$ \\
\hline & (18.07) & (16.72) & (18.18) & (16.85) \\
\hline \multirow[t]{2}{*}{ far } & $0.000791^{* * *}$ & $0.000783^{* * *}$ & $0.000774^{* * *}$ & $0.000766^{* * *}$ \\
\hline & (5.75) & $(4.46)$ & (5.63) & (4.37) \\
\hline \multirow[t]{2}{*}{ employ } & 0.000558 & $0.00138^{* *}$ & 0.000783 & $0.00163^{* *}$ \\
\hline & (1.10) & $(2.13)$ & $(1.52)$ & $(2.48)$ \\
\hline \multirow[t]{2}{*}{ wage } & $0.000133^{* * *}$ & $0.000152^{* * *}$ & $0.000144^{* * *}$ & $0.000165^{* * *}$ \\
\hline & (3.70) & (3.32) & (3.98) & (3.58) \\
\hline \multirow[t]{2}{*}{ saving } & $-0.00166^{* * *}$ & $-0.000650^{* * * *}$ & $-0.00165^{* * * *}$ & $-0.000646^{* * *}$ \\
\hline & $(-14.54)$ & $(-4.47)$ & $(-14.54)$ & $(-4.46)$ \\
\hline \multirow[t]{2}{*}{ consume } & $0.293^{* * *}$ & $0.264^{* * *}$ & $0.292^{* * *}$ & $0.263^{* * *}$ \\
\hline & (30.24) & (21.38) & (30.19) & (21.34) \\
\hline \multirow[t]{2}{*}{ gov } & $0.00195^{* * *}$ & $0.00101^{* *}$ & $0.00194^{* * *}$ & $0.000988^{* *}$ \\
\hline & $(5.32)$ & $(2.16)$ & $(5.29)$ & $(2.12)$ \\
\hline \multirow[t]{2}{*}{ tech } & $-0.0183^{*}$ & -0.0187 & -0.0161 & -0.0162 \\
\hline & $(-1.68)$ & $(-1.35)$ & $(-1.48)$ & $(-1.16)$ \\
\hline \multirow[t]{2}{*}{ _cons } & $8.106^{* * *}$ & $2.133^{* * *}$ & $8.102^{* * *}$ & $2.119^{* * * *}$ \\
\hline & $(50.56)$ & (10.43) & (50.56) & (10.37) \\
\hline$N$ & 2670 & 2670 & 2670 & 2670 \\
\hline$R^{2}$ & 0.815 & 0.699 & 0.816 & 0.700 \\
\hline
\end{tabular}

Note. The parentheses are the t-test values, *,**,*** indicate significance level of $10 \%, 5 \%$, and $1 \%$, respectively.

As shown in Table 8, this paper finds that the DDD item is still significant, which can prove that the great economic situation of sub-provincial cities is not due to the engagement of the B\&R strategy. Objectively, it can also be convinced that the B\&R policy has promoting effects on regions with low competitiveness and lagging development. In comparison to Table 4 (DID test), it is found that employ has a significant positive effect on the lngdpper in column (2) in Table 8. This shows that the policy may enhance the employment level of some 
prefecture-level cities along the eastern $B \& R$ route, thereby driving the economic growth. In addition, tech has no significant effect on lngdp and lngdpper in Table 4, but it has significant effect on inhibiting economic development in column (2) of Table 8. This indicates that in non-sub-provincial cities along the eastern B\&R route, the expenditure on science and technology research has a restraining impact on economic growth in the short term. In other words, the input and output of science and technology in non-sub-provincial cities is too small to make up for the negative effects brought by this kind of expenditure. In column (4) of Table 8, employ has a significant promoting effect on the per capita GDP of non-sub-provincial cities in the central and western regions along the $\mathrm{B} \& \mathrm{R}$ routes. However, prior to excluding sub-provincial city data (DDD test), employ had a significant inhibitory effect on regional economic development along the central and western regions. Therefore, it can be considered that employ has a greater promoting effect on the per capita GDP of non-sub-provincial cities along the central and western part of B\&R routes than it does on the per capita GDP of sub-provincial cities in the same areas. Accordingly, the result demonstrates a positive and significant boost to GDP per capita. The B\&R policy has created more jobs for non-sub-provincial cities along the central and western regions to improve local economic situation.

\subsubsection{Marketization Degree}

Not only has the Chinese reform and opening up stimulated the process of economic development, but it also accelerated the marketization degree. Along the $B \& R$ routes, there are many regions that have entered the echelons of relatively high marketization index. Fan and Wang (2019) released the 2018 marketization index report of China's provinces. According to this report, the samples were divided into two sets. One group is featured with marketization index lower than the national average (1574 samples), and another group is featured with marketization index higher than the national average (1286 samples). The DID regression method was performed respectively for these two data sets.

Table 9. Heterogeneity test of marketization degree (low marketization degree)

\begin{tabular}{ccc}
\hline & $(1)$ lngdp & $(2)$ lngdpper \\
\hline treated & & \\
after & $0.216^{* * *}$ & $0.193^{* * *}$ \\
& $(15.29)$ & $(10.17)$ \\
did & $0.0406^{* * *}$ & $0.0563^{* * *}$ \\
& $(2.76)$ & $(2.85)$ \\
industry & $0.0389^{* * *}$ & $0.0445^{* * *}$ \\
& $(20.67)$ & $(17.66)$ \\
tertiary & $0.0271^{* * *}$ & $0.0322^{* * *}$ \\
& $(11.30)$ & $(10.05)$ \\
far & $0.00207^{* * *}$ & $0.00134^{* * *}$ \\
& $(9.11)$ & $(4.43)$ \\
employ & $-0.000663^{* * *}$ & $-0.000734^{* *}$ \\
& $(-3.06)$ & $(-2.53)$ \\
wage & 0.00000122 & 0.0000297 \\
& $(0.03)$ & $(0.52)$ \\
saving & $-0.000747^{* * *}$ & -0.000215 \\
& $(-3.57)$ & $(-0.77)$ \\
consume & $0.219^{* * *}$ & $0.219^{* * *}$ \\
& $(18.10)$ & $(13.54)$ \\
gov & $0.00123^{* * *}$ & 0.000698 \\
& $(2.89)$ & $(1.23)$ \\
tech & 0.0124 & 0.00178 \\
& $(0.83)$ & $(0.09)$ \\
& $9.208^{* * *}$ & $3.090^{* * *}$ \\
& $(43.42)$ & $(10.88)$ \\
\hline & 1574 & 1574 \\
& 0.785 & 0.660 \\
\hline
\end{tabular}

Note. The parentheses are the t-test values, *, **, *** indicate significance level of $10 \%, 5 \%$, and $1 \%$, respectively. 
Table 10. Heterogeneity test of marketization degree (high marketization degree)

\begin{tabular}{ccc}
\hline & $(1)$ lngdp & $(2)$ lngdpper \\
\hline treated & $0.0349^{* * * *}$ & \\
after & $(3.31)$ & 0.0179 \\
& -0.0126 & $(1.25)$ \\
did & $(-1.22)$ & $0.0339^{* *}$ \\
& $0.0336^{* * *}$ & $(2.44)$ \\
industry & $(16.62)$ & $0.0544^{* * *}$ \\
& $0.0239^{* * *}$ & $(19.82)$ \\
tertiary & $(9.68)$ & $0.0475^{* * *}$ \\
& -0.0000637 & $(14.20)$ \\
far & $(-0.44)$ & $0.000706^{* * *}$ \\
& $0.00121^{* * *}$ & $(3.56)$ \\
employ & $(3.01)$ & $0.00381^{* * *}$ \\
& $0.00146^{* * *}$ & $(7.01)$ \\
wage & $(16.28)$ & $0.000923^{* * *}$ \\
& $-0.00118^{* * *}$ & $(7.60)$ \\
saving & $(-9.37)$ & $-0.000643^{* * *}$ \\
& $0.379^{* * * *}$ & $(-3.75)$ \\
consume & $(25.75)$ & $0.274^{* * * *}$ \\
& $0.00282^{* * *}$ & $(13.76)$ \\
gov & $(4.20)$ & $0.00258^{* * *}$ \\
& -0.00556 & $(2.84)$ \\
& $(-0.43)$ & $-0.0417^{* * *}$ \\
& $7.455^{* * *}$ & $(-2.35)$ \\
& $(31.16)$ & $1.046^{* * *}$ \\
& 1286 & $(3.23)$ \\
\hline & 0.911 & 1286 \\
& & 0.795 \\
\hline
\end{tabular}

Note. The parentheses are the t-test values, *,**,*** indicate significance level of $10 \%, 5 \%$, and $1 \%$, respectively.

On the whole, it can be seen that the B\&R policy can promote the economic development of key participating provinces along the routes whose marketization degree is lower than the national average (see Table 9). Among the control variables, industry, tertiary, far and consume are supposed to significantly enhance the economic development, both in terms of GDP and GDP per capita (under 1\% significance level). However, employ has an obvious inhibiting effect on GDP, indicating that marketization requires a higher quality of labor force.

As can be seen from Table 10, the B\&R policy also has a positive effect on the economic development of key participating provinces along the routes whose marketization degree is higher than the national average (under 5\% significance level). Among these variables, it is noted that industry, tertiary, employment, wage, consumption, and gov have significant promoting effects on lngdp and lngdpper. In comparison with Table 9 , wage and employ in Table 10 are two variables that have positive influences on regions with a high marketization degree (under 1\% significance level). The reason is that the regions with higher degree of marketization have stronger capability of absorbing employment than those with lower degree of marketization. Hence, marketization requires higher human resources flow, and the relationship between talent quality and employment plays an important role in the development of enterprises.

In summary, this paper finds that the $\mathrm{B} \& \mathrm{R}$ initiative has a more obvious boosting impact on regions with a high marketization degree, compared with regions with a low marketization degree along the routes.

\subsection{The Mechanism for Economic Development}

From the results of previous tests, we can find the significant factors for improving the Chinese economy along the B\&R. Furthermore, this paper identifies the fundamental mechanism behind the policy by observing the effects of these drivers for economic growth. 
Table 11. The mechanism of the B\&R policy for economic development

\begin{tabular}{|c|c|c|c|c|c|c|c|c|c|}
\hline & $\begin{array}{c}\text { (1) } \\
\text { industry }\end{array}$ & $\begin{array}{c}(2) \\
\text { tertiary }\end{array}$ & $\begin{array}{l}(3) \\
\text { far }\end{array}$ & $\begin{array}{c}\text { (4) } \\
\text { employ }\end{array}$ & $\begin{array}{c}(5) \\
\text { wage } \\
\end{array}$ & $\begin{array}{c}(6) \\
\text { saving } \\
\end{array}$ & $\begin{array}{c}(7) \\
\text { consume }\end{array}$ & $\begin{array}{l}(8) \\
\text { gov }\end{array}$ & $\begin{array}{c}(9) \\
\text { tech }\end{array}$ \\
\hline \multicolumn{10}{|l|}{ treated } \\
\hline \multirow[t]{2}{*}{ after } & $-5.097^{* * *}$ & $6.172^{* * *}$ & $15.20^{* *}$ & $4.346^{* * *}$ & $106.4^{* * *}$ & 3.923 & $0.539^{* * * *}$ & $2.676^{* *}$ & 0.0873 \\
\hline & $(-12.98)$ & (18.67) & (1.97) & (13.57) & (14.02) & $(0.41)$ & $(22.87)$ & $(2.00)$ & $(1.25)$ \\
\hline \multirow[t]{2}{*}{ did } & $1.356^{* * *}$ & $-1.498^{* * *}$ & 13.31 & -0.569 & -7.584 & $24.95^{* *}$ & -0.0363 & $3.550^{* *}$ & $0.164^{*}$ \\
\hline & $(2.58)$ & $(-3.45)$ & $(1.30)$ & $(-1.34)$ & $(-0.76)$ & $(1.98)$ & $(-1.17)$ & $(2.01)$ & $(1.78)$ \\
\hline \\
\hline $\operatorname{trcw}$ & & & & & & & & & \\
\hline \multirow[t]{2}{*}{ after*cen } & $4.406^{* * * *}$ & $-2.893^{* * *}$ & 11.83 & $-2.630^{* * *}$ & $-42.38^{* * * *}$ & 7.000 & $0.0494^{*}$ & -0.0763 & 0.0130 \\
\hline & $(9.41)$ & $(-7.42)$ & (1.30) & $(-6.96)$ & $(-4.75)$ & $(0.62)$ & (1.79) & $(-0.05)$ & $(0.16)$ \\
\hline \multirow[t]{2}{*}{ ddd } & $-2.924^{* * *}$ & $1.659^{* * *}$ & $-21.45^{*}$ & -0.497 & -13.57 & $-27.11^{*}$ & 0.0111 & -1.562 & $-0.238^{* *}$ \\
\hline & $(-4.50)$ & $(3.11)$ & $(-1.70)$ & $(-0.95)$ & $(-1.10)$ & $(-1.75)$ & $(0.29)$ & $(-0.72)$ & $(-2.10)$ \\
\hline \multirow[t]{2}{*}{ _cons } & $50.42^{* * *}$ & $35.51^{* * *}$ & $64.25^{* * *}$ & $10.25^{* * *}$ & $207.2^{* * *}$ & $67.72^{* * *}$ & $14.41^{* * *}$ & $16.52^{* * * *}$ & $0.161^{* * *}$ \\
\hline & (520.84) & (448.92) & (34.59) & (132.65) & (114.27) & (29.79) & (2572.59) & $(51.84)$ & $(9.67)$ \\
\hline$N$ & 2821 & 2786 & 2757 & 2744 & 2726 & 2722 & 2722 & 2715 & 2711 \\
\hline$R^{2}$ & 0.123 & 0.305 & 0.026 & 0.154 & 0.217 & 0.007 & 0.618 & 0.027 & 0.010 \\
\hline
\end{tabular}

Note. The parentheses are the t-test values, *,**,*** indicate significance level of $10 \%, 5 \%$, and $1 \%$, respectively.

In Table 11, the DID item shows that industry, saving, gov, and tech have significant promoting effects on the economic development of areas along the routes. Nevertheless, tertiary has a relatively obvious adverse effect on economic growth. From the previous analysis, it is highlighted that the high saving rate is not conducive to economic development, whereas in the mechanism test, saving has a more significantly promoting role. The underlying cause may be that considerable capital reserves are beneficial for foreign and domestic investments, which is a key point of the B\&R policy. Besides, the variable tech has a significant positive effect, which is different from the previous outcome. This proves that the B\&R strategy has indeed promoted the progress of science and technology along the routes, which in turn has also enhanced the development of the economy. However, the early promotion effect is not that apparent due to the short implementation time, the long period of input return and the inadequate government investments in science and technology. As for the DDD item, tertiary has a significant role of advancing the economy for areas along the B\&R, especially for areas in the mid-west of China. In contrast, industry, far, saving and tech are proved to embrace obvious inhibitory effects.

In conclusion, this paper finds that the secondary industry, scientific and technological innovation, government management and savings (in the market for loanable funds) have significant promoting effects on the economic development in regions along the $\mathrm{B} \& \mathrm{R}$. These factors all fall within the scope of the influence mechanism of the $B \& R$ policy. Additionally, in the central and western areas, the impacts of the tertiary industry far exceed other elements. By boosting the tertiary industry, the B\&R initiative drives the economic development in the mid-west regions, which proves the importance of the tertiary industry during the transformation of industry structure.

\section{Conclusion and Policy Implications}

As China's another opening-up strategy in the 21 st century, the B\&R policy is supposed to have achieved great results and facilitated the economic development of key participating provinces along the Belt and Road. However, with the gradual implementation, there are also some shortcomings. Under the circumstance, comprehensive and accurate evaluations of the B\&R strategy are the focus of concern in the world. From the empirical outcomes, the $\boldsymbol{H}_{1}, \boldsymbol{H}_{2}$ and $\boldsymbol{H}_{3}$ are all verified. Although the policy effects may be limited due to the lag, the results basically show that the B\&R strategy has a significant role in promoting the GDP and GDP per capita in regions along the routes, through factors involving the upgrading of the secondary industry, the rapid development of the tertiary industry, substantial investments, effective leadership of local governments and continuous technology input. After dividing the regions along the routes into the eastern part and the central and western part, this paper discovers that the $\mathrm{B} \& \mathrm{R}$ initiative is beneficial for the transformation of industry structure in the mid-west of China and the tertiary industry is emphasized as one of the largest driving forces. When the provincial cities and municipalities directly under the central government are removed, it can be found that the positive influences of the B\&R strategy in these regions are still significant. This confirms the original intention of the policy to promote economic development in the Chinese general cities. Moreover, when the areas along the routes are graded according to the degree of marketization, it is highlighted that the $B \& R$ strategy is more effective for the cities with a high level of marketization. Finally, based on the mechanism test, it is further 
verified that industrial transformation and upgrading are important for economic development. The R\&D investments may not be a cost-effective project for the economy in the short-term, while it may become one of the main drivers of economic growth in the future. On the contrary, the excessive saving rate has been regarded as a major factor that impedes economic development since it will inhibit consumption and reduce spending.

According to the empirical analysis of this paper, during the implementation of the B\&R initiative, relevant supporting policies should be formulated as soon as possible and enforced effectively. Different development strategies should be adopted for corresponding regions to promote the high-speed economic development of the regions along the routes.

Firstly, it is feasible to intensify infrastructure construction for areas along the B\&R. Due to historical and geographical factors, China's regional development is unbalanced, especially for the level of infrastructure. To illustrate, the east coast areas have established advantages in terms of economic growth and many policies favor these regions. Nonetheless, the economic development in central and western China lags far behind those areas due to the deteriorated environment, large distances from the coastline and the underdeveloped transportation systems. To strengthen the regional flow of factors and economic linkages, it is necessary to enhance the infrastructure construction from the eastern coast to the central and western inland. Moreover, it is inadequate to merely rely on the B\&R as a national strategy. The follow-up of relevant policies by local governments is an effective means to implement the national will, which requires the coordination and support of various departments to ensure the development quality of the B\&R policy along the routes.

Secondly, capital from the eastern regions should be encouraged to invest more in the provinces and cities along the B\&R in the central and western areas. At present, China is in a period of industrial transformation and upgrading, and economic growth is slowing down. During the whole changing process, if capital cannot find suitable investment opportunities, it will drift away or flow abroad. The failure of capital to enter the industry in a timely and effective manner, will reduce the efficiency and increase the cost, which may even lead to the instability of the capital market. Hence, the economic construction of provinces and cities along the routes can effectively absorb social capital and create investment chances. These include the import and export trade, other related industries of the cluster development and many more. It is vital for the government to strengthen the establishment of capital channels and actively attract investments.

Thirdly, we should seek a high-quality development model based on the potential originated from the soft environment. Through empirical research, it is found that the B\&R strategy has a particularly significant effect on the economic promotion of the central and western regions. However, due to the short implementation time of the strategy, the policy effect lags. Therefore, as to stimulate the rapid development of the economy in the long run, it is fundamental to construct the long-term mechanism and attach importance to the construction of the soft environment. Green advancement of the regional economy, protection of the ecological environment, construction of social civilization, improvement of laws and regulations and investment in scientific and technological areas can be considered.

\section{References}

Deng, X., Li, S. Q., \& Yuan, M. (2020). Evaluation of Policy Effects in 20 Years of Western Development Strategy: Based on Panel Data. Journal of Southwest University for Nationalities (Humanities \& Social Science Edition), 41(1), 107-114.

Fan, G., Wang, X. L., \& Hu, L. P. (2019). Marketization Index of China's provinces: NERI Report 2018. Social Sciences Academic Press.

Gan, W. Y., Xu, X. X., \& Yi, J. (2011). Achievement, Problems, and Countermeasures for Implementation of Western Development Strategy. Economic Geography, 31(1), 40-46. https://doi.org/10.15957/j.cnki.jjdl.2011.01.014

He, C. (2017). The Policy Factors of Economic Stall in Northeast Region-Based on the Inspection of the "Northeast Revitalization" Policy Effect. Reform of Economic System, 1, 44-49.

Hu, Z. G., \& Chen, Y. J. (2019). The Study of the Factors that Influence the Economic Growth Rate of Northeast China. China Price, 2, 40-43.

Jia, Y. N. (2018). Policy Evaluation and Promotion Path Research of Northeast Revitalization Strategy - Empirical Analysis Based on the PSM-DID Method. Inquiry Into Economic, (12), 41-53.

Peng, S. Y., \& Tu, Z. G. (2017). China's Market-oriented Reform and Job Changes in Industrial Enterprises:1998-2008. Inquiry Into Economic, (4), 26-38. 
Sun, Y. L., Li, G., \& Shi, D. Q. (2019). Western Development and Technological Innovation: Spillover or Trap? Re-examination Based on PSM-DID. Journal of Yunnan Finance and Trade Institute, 6, 51-62. https://doi.org/10.16537/j.cnki.jynufe.000451

\section{Copyrights}

Copyright for this article is retained by the author(s), with first publication rights granted to the journal.

This is an open-access article distributed under the terms and conditions of the Creative Commons Attribution license (http://creativecommons.org/licenses/by/4.0/). 